\title{
Hypomethylation Of The Hepc Genome In High D- Glucose Concentrations: Initiation Of Angiogenic Failure?
}

\author{
Paulina Fernández-Garcés \\ University of Concepción \\ Marcela Hinojosa-Moreno \\ University of Concepción \\ Soraya Gutierrez Gallegos ( $\nabla$ sgutierr@udec.cl ) \\ University of Concepción
}

\section{Research Article}

Keywords: Type 2 diabetes mellitus, Endothelial Progenitor Cells, hypomethylation.

Posted Date: February 17th, 2022

DOI: https://doi.org/10.21203/rs.3.rs-1339725/v1

License: (c) (i) This work is licensed under a Creative Commons Attribution 4.0 International License.

Read Full License 


\section{Abstract}

Background: Accumulating evidence suggests that Diabetes mellitus type 2 affects the angiogenic functions of Endothelial Progenitor Cells and a good glycemic control is not enough to restore these functions. Therefore, it is necessary to investigate if there are changes at the epigenetic level that can explain this phenomenon.

Results: We isolated EPC from mononuclear cells and cultured them in $5 \mathrm{mM}$ of D-glucose equivalent to normal glycemia, $10 \mathrm{mM}$ equivalent to a glycemia clinically acceptable for a diabetic patient, and $20 \mathrm{mM}$ of D-glucose corresponding to a value of glycemia in a patient with poor glycemic control; and we evaluated the adhesion capacity of EPC to fibronectin matrix. We also determined global methylation levels by slot blot for the 5-methylcytocine and 5-hydroxymethylcytocine and the expression levels of the TET1 and TET2 genes using qPCR. We found that high glucose concentrations do not affect EPC differentiation. Cells grown at $10 \mathrm{mM}$ D-glucose do not decrease their adhesion to fibronectin matrix but at $20 \mathrm{mM}$ culture we observed decrease in their adhesion ( $p>0.05$ ), but interesting, in both culture conditions we observed hypomethylation of the genome ( $p>0.05)$ accompanied with an increase in 5hydroxymethylcytocine in cells treated with $20 \mathrm{mM}$ D-glucose $(p<0.05)$. We did not observe statistically significant changes in the mRNA levels of the TET1 and TET2 genes. Treatment with demethylating agent 5-aza-2'-deoxycytidine, shows that adhesion failure is dependent on genome demethylation ( $p>$ $0.001)$.

Conclusions: High concentrations of D-glucose $(20 \mathrm{mM})$ generate an active hypomethylation of the hEPC genome and a decrease in their adhesion capacity. Although the concentration of D-Glucose considered as "clinically acceptable" glycemia in a diabetic patient $(10 \mathrm{mM})$, do not produce significant changes in hEPC adhesion to fibronectin matrix, a global hypomethylation of the genome, was observed, which could be responsible for impair angiogenic functions of the hEPC in patients with good glycemic control.

\section{Background}

Type 2 diabetes mellitus is a pathology generated by a deficit in insulin secretion or by an incorrect use of it by the body; both environmental factors and genetic susceptibility play a fundamental role in its development (Alberti and Zimmet, 1998; Guo et al., 2020).

According to The International Diabetes Federation (IDF) in 2019 there were 463 million people worldwide with diabetes ages 20 to 99 . It is estimated that by the year 2030 the number of diabetics will reach 578 million and by 2045 will be 700 million; corresponding to $90 \%$ of world population approximately (Federation, 2019; Saeedi et al., 2019).

This complex pathology is defined as a metabolic disease, characterized by permanent hyperglycemia (Cencioni et al., 2014; Schmidt, 2018), which results in complications of microvascular origin, such as diabetic retinopathy, diabetic neuropathy, diabetic nephropathy and macrovascular 
complications such as ischemic heart disease, peripheral vascular disease and cerebrovascular disease (Forslund and Archdeacon, 2015; Federation, 2019; Doumas et al., 2020).

In the vascular lesion, the organism responds through re-endothelialization and angiogenesis for the restoration of vascular homeostasis (Pearson, 2009) process in which participate the Human Endothelial Progenitor Cells (hEPC). hEPC are characterized by being unipotent cells with the capacity for selfrenewal, proliferation and differentiation (Chopra et al., 2018). They were described for the first time by Asahara et al. in 1997 (Asahara et al., 1997) after that, different studies have demonstrated that $\mathrm{CD} 34+/ \mathrm{KDR}+$ hematopoietic cells isolated from peripheral blood can differentiate into endothelial cells contributing to formation of new vasculature in hypoxic/ischemic conditions (Jujo et al., 2008; Marçola and Rodrigues, 2015). Identification of hEPCs is carried out using a panel of markers, such as CD34+/KDR+/CD133+/CD31+/Willebrand factor and VE-cadherin in more advanced maturation stages (Xing et al., 2020).

hEPCs isolated from type 2 diabetes patients exhibit impaired angiogenic properties. Results from Tepper 's research group demonstrated that hEPC isolated from type 2 diabetes patients, exhibit less proliferation in cell culture, less adhesion to Human Umbilical Cord Vein cells (HUVECs) and less integration to a pre-existing tubular network formed by Human Microvasculature Endothelial Cells (MVEC) when compared to hEPC isolated from healthy patients. These studies also showed an inversely proportional correlation among hEPC functions and Glycated Hemoglobin (HbA1c) levels (Tepper et al., 2002). Later Egan et al. (2008), reported that patients with type 2 diabetes have significantly lower levels of hEPC compared to patients without the disease $(p<0.05)$ (Egan et al., 2008). Similar results have been obtained by others researchers, who evidenced a decrease in proliferation, adhesion, angiogenesis capacity and mobility (Yue et al., 2011) as well as a decrease in hEPC maturation and differentiation (Kang et al., 2017).

Loss of hEPC functions in type 2 diabetes is associated with progressive vascular deterioration. Egan's research group, followed 98 patients with type 2 diabetes for 10 years of whom 15,3\% died due to cardiovascular and vascular events associated with a $50 \%$ decrease in circulating EPC levels. Thus, the authors concluded that low EPC levels can independently predict increased risk of mortality over a 10year period in type 2 diabetes patients (Egan et al., 2018).

The UK Prospective Diabetes Study demonstrated that intensive glycemic control resulted in a beneficial effect by reducing the risk of diabetic complications such as adverse cardiovascular events and mortality. (UKPDS Group 1998; Holman et al., 2008). Additionally, Patel et al. showed that intensifying glycemic control in patients with type 2 diabetes ( $\mathrm{HbA} 1 \mathrm{c}$ of $6.5 \%$ or less) produced a relative reduction of $10 \%$ in the combined result of major macrovascular and microvascular events (Patel et al., 2008). Accordingly, the American Diabetes Association has established that maintaining adequate glycemic control is the cornerstone of diabetes care (Association, 2018).

However, in the context of hEPC, this does not seem to be sufficient. It has been reported that in diabetic patients, despite reaching the clinical therapeutic objective ( $\mathrm{HbA} 1 \mathrm{c}<7 \%)$, the in vitro proliferative potential 
and the number of circulating hEPCs is only partially corrected (approximately 60\%), not reaching the levels of cells present in healthy patients ( $<$ 0.001) (Churdchomjan et al., 2010; Balestrieri et al., 2013). Therefore, the diabetic patient during their life will progressively develop the vascular complications associated to type 2 diabetes, despite being "clinically controlled", because a subtle but permanent hyperglycemic environment generates a decrease in number, migration capacity and adhesion of hEPC.

Changes in cellular function in response to modifications in the cell environment are regulated by epigenetic mechanisms, which are defined as heritable changes that affect gene expression without altering the underlying genomic sequence (Ling and Rönn, 2019). These processes include RNA-based mechanisms, histone modification and changes in DNA methylation (Zhang et al., 2020), being the latter the most widely studied and best characterized epigenetic mechanism, and involves the covalent addition of a methyl group to carbon $\mathrm{C} 5$ of cytosine nucleotides to generate 5-methylcytosine (5mC) (Unnikrishnan et al., 2019).

A global increase in DNA methylation has been observed in peripheral blood cells of

patients with type 2 diabetes compared to healthy controls patients; moreover, DNA methylation in diabetic patients exhibit a positive correlation with $\mathrm{HbA} 1 \mathrm{c}$ percentage (Chen et al., 2007; Pinzón-Cortés et al., 2017). Similarly, Wu's research group, report that the long-interspersed element (LINE) sequences in the leukocyte DNA of type 2 diabetes patients were hypomethylated when compared to normal patients (49.60 \pm 14.55 vs. $37.81 \pm 9.07, \mathrm{P}<0.001)$ (Wu et al., 2017). These observations highlight the impact of hyperglycemia in the circulating cells like hEPC.

Considering the results described above, as well as the functional alteration that hEPC exhibit in type 2 diabetic patients with good glycemic control, the present study aims to evaluate whether clinically acceptable glucose concentrations for a diabetic patient could generate changes in the methylation levels of the hEPC genome which results in decrease adhesion capacity and angiogenic failure

\section{Methods}

\section{Human blood samples:}

All procedures performed in this study follow the Declaration of Helsinki for the Ethical Treatment of Human Subjects. Our study was approved by the Scientific Ethics Committee Health Service of Concepción (approval number 19-10-102) and written informed consents were obtained from each participant.

Donors were recruited within the city of Concepción, through the non-probabilistic "snowball" sampling technique, being included in the study all those who present a normal glycemic profile (fasting glucose between 80 and $100 \mathrm{mg} / \mathrm{dl}$ ) and excluded from the study all those who are smokers, have hematological alterations or sexually transmitted diseases, are experiencing a viral or bacterial infection, pregnant or lactating women and who did not sign the informed consent (Table 1). 
Each donor underwent a phlebotomy in the vein of the arm to first obtain a $3 \mathrm{ml}$ sample in a collection tube with EDTA (to measure glycemia and glycosylated hemoglobin) and then a volume of approximately $50 \mathrm{ml}$ of blood was taken with Buffer Saline 1X phosphate (1X PBS) and EDTA (5mM) (PBSE) for cell culture. Both samples were taken at the same opportunity using a sterile syringe.

Blood samples and the cell cultures were process according to the Manual of Biosafety Standards and Associated Risks-Fondecyt-CONICYT (2018) and the biosafety standards of the Facultad de Ciencias Biológicas, Universidad de Concepción.

\section{Cell culture:}

Endothelial progenitor cells were isolated as described by Asahara and Vasa (Asahara et al., 1997; Vasa et al., 2001). 50mL of whole blood was mixed with a 5mM PBSE solution, then the mononuclear cells were extracted using a density gradient using Histopaque 1070 (Sigma Chemical, Sigma Chemica Co, St Luis, MO), washed, resuspended in PBSE and finally seeded in culture medium for endothelial cells (GIBCO BRL Life Technologies, Bethesda, MD, USA), supplemented with $20 \%$ of fetal bovine serum (Biological Industries, Israel) and growth factor for endothelial cells $(10 \mu \mathrm{g} / \mathrm{ml}$; GIBCO BRL Life Technologies, Bethesda, MD, USA). Culture plates were pretreated by covering them with fibronectin (1 $\mu \mathrm{g} / \mathrm{ml}$, Sigma) for five minutes, then the fibronectin was removed. Cells were cultured at $37^{\circ} \mathrm{C}$ under a $5 \%$ CO2 atmosphere for four days.

\section{Flow cytometry:}

hEPC were detached, using 0,25\% -1X trypsin (Hyclone) for 3 to 5 minutes and then counted in a Newbauer chamber, using the trypan blue exclusion technique. Subsequently, $1 \times 10^{5}$ cells were incubated for $20 \mathrm{~min}\left(22^{\circ} \mathrm{C}\right)$ with $20 \mu \mathrm{l}$ of rabbit anti-human CD34 monoclonal antibody bound to APC (Becton Dickinson, San Diego, CA) and 40 $\mu$ l of rabbit anti-KDR antibody (R\&D System Inc., Minneapolis, Minnesota). Flow Cytometry analyzes were performed in Cell Sorter BD FACSAria III Flow Cytometer at CMA Bío-Bío Advanced Microscopy Center, where the percentages of cell subpopulations CD34+/KDR-; $\mathrm{CD} 34+/ K D R+$ and $C D 34-/ K D R+$ in each sample was determined.

\section{RNA extraction and cDNA synthesis:}

Total RNA was extracted from the hEPC- 4d using Direct-zol RNA (Zymo Research) following the manufacturer's instructions. For cDNA synthesis we used $2 \mu \mathrm{g}$ of RNA per reaction, $0.5 \mu \mathrm{g}$ of Oligo dT primer and water ( $15 \mu \mathrm{L}$ final volume), each tube was incubated for 5 minutes at $70^{\circ} \mathrm{C}$, then we used $5 \mathrm{X}$ M-MLV buffer, dNTP (25 mM final concentration), 25 units of ribonuclease inhibitor (Invitrogen), 200 units of M-MLV RT (Invitrogen) and nuclease-free water ( $25 \mu \mathrm{L}$ final volume for reaction), each tube was incubated for 60 minutes at $42^{\circ} \mathrm{C}$. The cDNA obtained was stored at $-20^{\circ} \mathrm{C}$.

\section{Determination of gene expression by PCR and QPCR}


To assess the expression of the messenger RNA of the CD31, OCT-4 and CD34 genes and to quantify the expression of the genes TET1 and TET2, $1 \mu \mathrm{L}$ of $\mathrm{CDNA}$ from the Maxima ${ }^{\circledR}$ SYBER Green/Rox qPCR Mater mix $1 x$ (Thermo Scientific) was used for PCR with $0,3 \mu \mathrm{M}$ of each forward and reverse primer and using the SNRPD3 as a reference gene. Oligonucleotide primers used for amplification were CD31 (forward) 5'CAACAGACATGGCAACAAGG-3', (reverse) 5'-TTCTGGATGGTGAAGTTGGC-3', OCT-4 (forward) 5'CTTGCTGCAGAAGTGGGTGGAGGAA-3, (reverse) 3'-CTGCAGTGTGGGTTTCGGGCA-3', CD34 (forward) 5'AATGAGGCCACAACAAACATCACA-3', (reverse) 5'- CTGTCCTTCTTAAACTCCGCACAGC-3', TET1 (forward) 5'-TTCGTCACTGCCAACCTTAG-3', (reverse) 3'-ATGCCTCTTTCACTGGGTG-5', TET2 (forward) 5'TTTGCTCCTGTTGAGTTACA-3', (reverse) 5'-CCACTTGGTGTCTCCATTTA-3', and SNRPD3 (forward) -5'TCTTCCTGCCAAGATGTCTA-3', (reverse) 5'-TAACATGGGTGCGTTCTTC-3.

Amplification cycles included a $95^{\circ}$ initial denaturation for 10 minutes, denaturation for 30 seconds and annealing for 40 seconds at $58^{\circ} \mathrm{C}(\mathrm{CD} 31), 60^{\circ} \mathrm{C}\left(\mathrm{OCT} 4\right.$ and CD34), $57^{\circ} \mathrm{C}$ (TET 1), $55^{\circ} \mathrm{C}$ (TET 2), $55^{\circ} \mathrm{C}$ (SNRPD3). Real-time PCR was carried out in Stratagene ${ }^{\circledR} \mathrm{M} \times 3000 \mathrm{P}^{\mathrm{TM}}$ Thermal Cycler and results obtained for SNRPD3, TET1 and TET2 gene were processed with the Mx3000P program and expressed as relative quantification of $\mathrm{mRNA}$, using the DDCt method and melting curve analysis.

Expected size products for CD31 (240 bp), OCT-4 (169 bp), CD34 (380 bp), TET1 (149 bp), TET2 (307 bp) and SNRPD3 (262 bp) were confirmed by $1 \%$ agarose gel electrophoresis in the presence of SYBR Safe (Invitrogen).

\section{Cell viability:}

hEPC cells were cultured for four days with different concentrations of D-glucose $(5,10$,

20, 30 and $35 \mathrm{mM}$ ), at four days of culture, the cells were detached with 0,25\%-1x trypsin (Hyclone), washed once with 1 X PBS, labeled with $0.4 \%$ trypan blue/PBS, and counted in a Newbauer chamber (cells grown in $5 \mathrm{mM}$ D-glucose were considered as 100 percent of cell viability). In these experiments, mannitol was used as an osmotic control.

\section{Genomic DNA extraction:}

The extraction of genomic DNA from the hEPCs was performed using a Nucleospin $\circledast$ blood columnbased extraction kit (Macherey-Nagel) following the manufacturer's instructions. Integrity of the extracted DNA was evaluated by $0.8 \%$ agarose gel electrophoresis in the presence of SYBR Safe (Invitrogen).

\section{Slot Blot for measurement of global $5 \mathrm{mC}$ and $5 \mathrm{hmC}$ :}

Genomic DNA extracted from cells cultured in high and normo D-glucose concentration was denatured with $0.1 \mathrm{M} \mathrm{NaOH}$ at $100^{\circ} \mathrm{C}$ for 10 minutes, then the reaction was neutralized with $6.6 \mathrm{M}$ ammonium acetate $\mathrm{pH} 7$ and the DNA was loaded and fixed on nylon membrane for subsequent blocking with $5 \%$ milk in $1 \mathrm{X}$ PBS - $0.5 \%$ tween for two hours. Then the membrane was incubated for two hours with primary anti-5'-methylcytosine antibody 1:1000 (Calbiochem), after this, the membrane was washed three times 
with $5 \%$ milk in 1 X PBS - $0.5 \%$ tween for ten minutes. Later the membrane was incubated for one hour with secondary anti-mouse IgG-HRP 1:500 (Santa Cruz Biotechnology) and washed three times with 5\% milk in 1X PBS - $0.5 \%$ tween for ten minutes. Finally, the membrane was revealed with Pierce $® E C L$ Western Blotting Substrate (Thermo Scientific) and exposed to film for 30 seconds.

Densitometric analysis was performed in the ImageJ program (NIH, MD, USA), and normalized to DNA present on the membrane. Presence of 5-hyroximethylcytosine was evaluated using a primary antibody anti-5'-hydroximethylcytosine 1:1000 (Calbiochem).

\section{hEPC adhesion to fibronectin matrix:}

24-well culture plates with cover slides inside were coated for 2 hours at $37^{\circ} \mathrm{C}$ with $100 \mu \mathrm{g} / \mathrm{ml}$ fibronectin, then the fibronectin was removed, and the cover slides were coated for 2 hours at $37^{\circ} \mathrm{C}$ with $1 \% \mathrm{BSA}$. After that time, BSA was removed and $3 \times 10^{5} \mathrm{hEPC}$ previously cultured at 5 and $20 \mathrm{mM}$ D-Glucose for four days, were plated on the cover slides and incubated for 1 hour at $37^{\circ} \mathrm{C}$. After incubation, unattached cells were gently removed with 1 X PBS and adhered cells were fixed with $4 \%$ paraformaldehyde (PFA) for 40 minutes. Finally, after removing the PFA and washing the wells three times, each cover slide was stained with DAPI dilution 1:100 (Sigma Aldrich) incubated for 30 minutes at room temperature in the dark to finally be mounted on a glass sheet. Twelve hours after assembly, the cells adhered to the fibronectin matrix were observed in fluorescence microscopy at Bío-Bío Advanced Microscopy Center (CMA) and 10 randomized fields per each cover slides were counted. Cells cultured with $5 \mathrm{mM}$ D-glucose were considered to represent $100 \%$ cell adhesion.

\section{Statistical analysis:}

Data was processed using Graph Prism software (San Diego, CA, U.S.A). Statistical significance analysis was performed by analysis of variance (ANOVA), as appropriate. The values were given as mean plus standard error, where $\mathrm{n}$ was the number of repetitions of the same test, a $\rho<0.05$ was considered as statistically significant.

\section{Results}

\section{Human mononuclear cells (MNCs) differentiate into Human Endothelial Progenitor cells (hEPC) in vitro.}

The hEPCs from diabetic patients have their basic angiogenic functions such as migration, the ability to form blood vessels and adhesion capacity altered; however, it is not entirely clear how hyperglycemia impacts these functions. Therefore, in order to understand how hyperglycemia can induce failure of hEPC adhesion, we used hEPC cultures as our biological model. hEPC were isolated from MNC primary culture derived from non-diabetic patients (Table 1). As can be seen in figures 1A and 1B, after four days of culture the cells showed a rounded shape, without morphological signs characteristic of a mature endothelial cell (splinde shape). To further characterized our cultures, we determined surface markers expression using reverse transcription polymerase chain reaction analysis RT-PCR. Our results 
demonstrate the presence of mRNA for markers of cell immaturity such as Oct-4 (169 bp) and CD34 (380 bp) (figure 1C upper and middle panel respectively, lanes 8 and 9), as well as mRNA expression for endothelial marker CD31 (240 bp) (figure 1C lower panel lanes 8 and 9).

mRNA expression is not a guarantee of protein expression; therefore, we additionally analyzed expression of the endothelial marker CD34 and KDR at protein level by flow cytometry as can be seen in Figure 1D, our results indicate the presence of three distinct cell subpopulations, one with immaturity characteristics but without endothelial characteristics (KDR-/CD34+) corresponding to $8,7 \%$ of the cell population; a second subpopulation without immaturity characteristics but with endothelial characteristics (KDR+/CD34-) corresponding to 16,7\% of the cell population and a third cell subpopulation with immature and endothelial characteristics (KDR+/CD34+), the one with the highest number of cells within the culture equivalent to $44 \%(p>0.01)$. Therefore, under our culture conditions, the higher percentage of cells exhibits an immature immunophenotype with endothelial characteristics. Taken together, our results indicate that from our four-day primary culture methodology, we obtain mainly hEPCs identified as CD34+ Oct $4+\mathrm{CD} 31+\mathrm{KDR}+$.

\section{High concentrations of D-glucose do not affect the identity of hEPCs or the integrity of their DNA.}

In order to evaluate how hyperglycemia, affect the adhesion of hEPC, it was necessary to simulate the physiological conditions in which the hEPC of diabetic patients are found. To this end, we cultured hEPC in media supplemented with $5-35 \mathrm{mM}$ of D-Glucose.

Our results show that under this conditions cell viability is close to $100 \%$ (Figure $2 \mathrm{~A}$ ). Although a slight decrease can be observed at $35 \mathrm{mM}$ glucose of D-glucose and $35 \mathrm{mM}$ mannitol (which was used as osmotic control), it is not statistically significant. Importantly in these growing conditions no DNA damage is observed (Figure 2B).

All following experiments were carried out using media supplemented with $5 \mathrm{mM}(90 \mathrm{mg} / \mathrm{dl})$ as a control since it is the concentration of D-glucose contained in the growth media and equivalent to normal glycemia, $10 \mathrm{mM}(180 \mathrm{mg} / \mathrm{dl})$ which is a clinically acceptable value for a diabetic patient, and $20 \mathrm{mM}$ of D-glucose $(360 \mathrm{mg} / \mathrm{dl})$ corresponding to the value of hyperglycemia in a patient with poor glycemic control.

To characterize cells growing under high glucose conditions we evaluated expression of the characteristic surface markers OCT4, CD34 and CD31. As show figure 2C, under all growing conditions hEPC exhibit expression of these markers (lanes 8 to 13), however, this expression seems not to be the same in the different treatments (5, 10 and $20 \mathrm{mM}$ of D-glucose), in the OCT-4 and CD34 genes. Moreover, as shown in Figure 2D, flow cytometry analysis of CD34 and KDR reveal the presence of the three previously described cell subpopulations KDR-/CD34+; KDR+/CD34-; KDR+/CD34+. All subpopulations exhibit similar distribution in media supplemented with $5 \mathrm{mM}, 10 \mathrm{mM}$ or $20 \mathrm{mM}$ D-glucose. Our population of interest, CD34+/KDR+ represent a 40,3\% (10mM D-glucose) and 40,5\% (20mM D-glucose), compared with cell grown in media supplemented with $5 \mathrm{mM}$ of D-glucose $44 \%$. Therefore, culturing hEPC cells in 
medium containing 5,10 and $20 \mathrm{mM}$ of D-glucose for four days does not affect cell viability, DNA integrity or cell populations distribution.

\section{Human Endothelial Progenitor Cell adhesion is impaired by high D-Glucose concentrations.}

hEPC from diabetic patients show a decreased adhesion capacity; therefore, in the following experiment we evaluate if this phenomenon is reproduced when cells are cultured in media supplemented with the selected D-glucose concentrations.

hEPC cultured at 5, 10 and $20 \mathrm{mM}$ of D-Glucose were grown in fibronectin matrix for 4 hours, adhered cells were subsequently counted by fluorescence microscopy (Figure 3A). Cell adhesion was quantified by counting the cells that adhered to fibronectin in different microscopic fields. As expected, there is a statistically significant decrease ( $p>0.05$ ) when cells were cultured in $20 \mathrm{mM}$ of D-glucose, a concentration that represents the glycemia from a patient with poor glycemic control (Figure 3B). Interestingly, when cells were cultured with $10 \mathrm{mM}$ D-glucose, which is equivalent to clinically acceptable hyperglycemia, no changes in adhesion activity were observed in comparison with the control of $5 \mathrm{mM}$ of D-glucose equivalent to a normal glycemia.

\section{High D-glucose generates global hypomethylation in human endothelial progenitor cells.}

Our results indicate that hEPC cultured in high concentrations of D-glucose $(20 \mathrm{mM})$ exhibit changes in its adhesion capacity. The most studied mechanisms by which the environment triggers changes at the gene expression level reflected in function are epigenetic modifications, such as miRNA-based mechanisms, histone modifications, and DNA methylation.

It is well documented that high glucose concentrations cause DNA damage which, when repaired by various enzymatic mechanisms, generate changes in the global methylation state of the genome. Therefore, we decided to evaluate changes that could be occurring in hEPC DNA methylation.

DNA methylation analysis was performed by slot blot using an anti-methylated DNA antibody. Ad seen in figure 4A, unmethylated DNA is not recognized by our antibody, thus demonstrating its specificity for the recognition of the 5-methylcytosine epitope.

As a positive control for the technique, we evaluated the effect of D-glucose on the methylation MNCs because previously published data show that the high D-glucose concentrations produces DNA hypermethylation in leucocytes (Wu et al., 2017). MNCs DNA was analyzed by a slot blot, using the total level of DNA (DNA stained on the membrane) to standardize the antibody signal. As can be seen in Figure 4B MNCs behave according to what was expected showing hypermethylation, with significantly statistically differences when cells cultured in media supplemented with $20 \mathrm{mM}$ of glucose is compared to control ( $p>0.05)$. Surprisingly, when hEPC where grown in $10 \mathrm{mM}$ and $20 \mathrm{mM}$ of D-Glucose we observed a decrease in the overall methylation of the genome compared to control, media containing of $5 \mathrm{mM}$ of D-Glucose, $(p>0.0001)$ (Figure $4 C)$. 
These results were unexpected considering that high glucose concentration generate hypermethylation in peripheral blood cells and hEPC are derived from them. Furthermore, we hypothesize that decrease in hEPC adhesion function could be result a silencing of the genes involved in this process, an effect triggered by DNA hypermethylation and not by DNA hypomethylation.

It is noteworthy that cells cultured at $10 \mathrm{mM} \mathrm{D-glucose} \mathrm{present} \mathrm{a} \mathrm{statistically} \mathrm{significant} \mathrm{hypomethylation}$ of the genome ( $p>0.001$ ) compared to the control of 5mM D-Glucose (figure 4C), even though, at this glucose concentration, no changes in cell adhesion activity were observed (Figure 3B).

\section{Demethylation of the hPEC genome leads to decreased cell adhesion}

Our results indicate that high concentrations of D-glucose in vitro induce a decrease in hEPC adhesion to fibronectin matrix and also cause hypomethylation of the genome. To evaluate whether there is a causal relationship between these two phenomena, D-glucose- independent DNA demethylation was induced in hEPC using 5-aza-2'-deoxycytidine (5 Aza-2dC).

Our results indicate that under these culture conditions cell viability is close to $100 \%$ (Figure 5A) and although slight decrease was observed in cultures treated with 5 Aza-2dC, this is not statistically significant; furthermore, no DNA damage was observed under these conditions (Figure 5B).

To characterize cells grown under demethylating conditions, we evaluated the expression of their characteristic surface markers OCT4, CD34 and CD31 and, as seen in Figure 5C, similar mRNA levels of markers OCT4, CD34 were observed for cells cultured with 5 Aza-2dC (lanes 10-11) and with DMSO (vehicle) (lanes 8-9) but apparently there is a decrease in the mRNA expression levels of the surface marker CD31 compared to control (lanes 6-7). As expected, 5 Aza-2dC induces a statistically significant hypomethylation hEPC genome compared to control $(p>0.001)$ and vehicle ( $p>0.01)$ (Figure 5D).

Moreover, hEPC adhesion to fibronectin matrix of cell treated with $5 \mathrm{Aza}-2 \mathrm{dC}$ was lower (Figure $5 \mathrm{E}$, right panel) compared to vehicle and control (Figure 5E, central panel and left panel respectively). Cell adhesion was quantified by counting the cells in different microscopic fields that adhered to fibronectin, observing a statistically significant decrease in cells cultured with $5 \mathrm{Aza}-2 \mathrm{dC}(\mathrm{p}>0.001)$ compared to the control and the vehicle (Figure 5F).

Therefore, our results indicate that global DNA hypomethylation of hEPC results in a

decreased cell adhesion capacity.

\section{High D-glucose causes active demethylation of the hEPC genome}

Our results indicate that culture hEPC in high D-glucose concentration results in DNA hypomethylation, to confirm that this effect was produced by the metabolism of D-glucose and not by an osmotic effect, cells were grown in media supplemented with $10 \mathrm{mM}$ and $20 \mathrm{mM} \mathrm{L-Glucose} \mathrm{(not} \mathrm{metabolizable).} \mathrm{As} \mathrm{observed} \mathrm{in}$ figure 6A, DNA methylation of hEPC cultured in $20 \mathrm{mM}$ L-Glucose does not exhibit statistically significant 
changes when compared to the control ( $5 \mathrm{mM}$ of D-Glucose). Therefore, these results demonstrate that Glucose must be metabolized (D-Glucose) to induce the hypomethylation of hEPC DNA.

It has been previously show that the increase in glucose metabolism generates DNA damage, which, when repaired, can lead to hypomethylation of the genome through the action of the enzymes TET1 and TET 2, which transform 5-methylcytosine $(5 \mathrm{mC})$ into 5-hydroxymethylcytosine (5hmC) (Lio and Rao, 2019; Yuan et al., 2019)

To evaluated if hEPC DNA hypomethylation is generated as result DNA repair activities, the levels of 5$\mathrm{hmC}$ in cells cultured with different concentrations of D-Glucose were measured through slot blot. As seen in Figure 6B, a statistically significant increase $(p<0.05)$ in the levels of 5 -hmC was observed in cells cultured with $20 \mathrm{mM}$ of D-glucose compared to the control and an increasing trend when they were cultured with $10 \mathrm{mM}$ of D-Glucose. Interestingly, although the expression of the TET1 and TET2 genes is observed in the three culture conditions (5, 10 and $20 \mathrm{mM}$ of D-glucose) (figure 6 and lines 8 to 16), no statistically significant changes in the expression levels of the messenger for TET1 and TET2 genes were observed when cells were cultured at the selected D-Glucose concentrations compared to the control (figure 6C and 6D).

Therefore, our results demonstrated that hEPC genome hypomethylation observed when cells were cultured in high concentrations D-Glucose is independent of TET1 and TET2 expression levels.

\section{Discussion}

The incidence and prevalence of Type 2 Diabetes increase every year and therefore, the complications associated with it. Evidence supporting a role for epigenetics in the development of complications derived from type 2 diabetes remains limited. In this study, hEPC (CD34+/KDR+) isolated from normal subjects were used to evaluate how high D-Glucose concentration affects the DNA methylation profile of hEPC and the impact it has in cell adhesion properties.

Because glycemic control is a cornerstone in preventing complications derived of type 2 diabetes (Henning, 2018), our study was carried out using $5 \mathrm{mM}$ of D-glucose $(90 \mathrm{mg} / \mathrm{dl})$ as value of normal hyperglycemia, $10 \mathrm{mM}$ of D-glucose $(180 \mathrm{mg} / \mathrm{dl})$ which is a clinically acceptable value for a diabetic patient, and $20 \mathrm{mM}$ of D-glucose $(360 \mathrm{mg} / \mathrm{dl})$ corresponding to the value of hyperglycemia in a patient with poor glycemic control.

Our results showed that high D-Glucose concentration (10mM and $20 \mathrm{mM})$ do not affect DNA integrity, cell viability or immunophenotype of hEPC (figure 2A-2D); but when cells are cultured with $20 \mathrm{mM}$ of DGlucose their adhesion capacity to fibronectin matrix is diminished in comparison with cell cultured in $10 \mathrm{mM}$ or $5 \mathrm{mM}$ D-Glucose (control).

Alteration in the hEPC adhesion was observed at four days of culture, in this same context, data in diabetic dyslipidemia mice, showed a diminished EPC adhesion which is evidently reduced in this cells at 
4 and 7 days after diabetes induction (Filippi et al., 2020). Thus, this evidence suggests that the environment plays a relevant role in the cell function.

In our study, when the hEPC were cultured in an environment with high D- Glucose concentrations (10mM and $20 \mathrm{mM}$ ), a decrease in the overall methylation of the genome was observed compared to control media containing $5 \mathrm{mM}$ of D-Glucose (figure $4 \mathrm{C}$ ). These results highlight the importance of good glycemic control. Interestingly, changes in DNA methylation were observed at four days at culture hEPC with $10 \mathrm{mM}$ of D-glucose, although cell adhesion was not yet affected (figure $3 A$ ).

Different reports have shown that type 2 diabetes generate specific gene hypomethylation (Tewari et al., 2012; Gong et al., 2014; Fu et al., 2020), Dayeh's research group analyzed 483,031 CpG sites in the isolated pancreatic beta cell genome of type 2 diabetes patients, observing a decrease in the percentage of global methylation of the genomic DNA compared to control patients (Dayeh et al., 2014). Similar results have been found by Nilsson et al. (2015), working with 455,526 hepatocyte genome sites from type 2 diabetic patients. Their results show a decrease in the percentage of global methylation of the regions studied (Nilsson et al., 2015), suggesting that hyperglycemia in type 2 diabetes can generate global DNA hypomethylation in the cell, as we observed in hEPCs.

Another characteristic of type 2 diabetes is the increase in oxidative stress, since high levels of Reactive Oxygen Species (ROS) are generated due to the excessive passage of electrons in the electron transport chain, as result of the high oxidation rate of glucose or lipids in the Krebs cycle (Brownlee, 2001).

Experimentally, it has been observed that oxidative stress, present in type 2 diabetic patients, affects the re-endothelialization property of hEPCs (Sorrentino et al., 2007). Likewise, cell proliferation, angiogenic functions as well as the recruitment to the area of vascular injury are impaired under these conditions (Chen et al., 2007; Hamed et al., 2009; Sambuceti et al., 2009).

Oxidative stress induces DNA breaks (Garcia Soriano F et al., 2001); the repair of which can change the methylation status of cell DNA (Dhliwayo et al., 2014). ROS cause DNA oxidation, generating lesions in nitrogen bases such as 8-hydroxy-2'-deoxyguanosine (8-OHdG) which negatively influence cytosine methylation affecting the methylation of adjacent sites, resulting in hypomethylation of the genome (Weitzman et al., 1994).

DNA methylation play central role in gene expression and therefore in the cellular function, existing a link between diabetes, DNA methylation status and cell function (Pinzón-Cortés et al., 2017; Yuan et al., 2019; Ouni et al., 2020; Parveen and Dhawan, 2021). Our result confirms this hypothesis, because when Dglucose- independent DNA demethylation was induced in hEPC, their adhesion decreased compared to untreated cells (figure 5F).

Genome demethylation can be passive, due to reduction or absence of the enzymes DNA dimethyl transferases (DNMT), or active, via DNA repair, through enzymes of ten-eleven translocation (Tet) (Bhutani et al., 2011; Wu et al., 2018). As mentioned earlier the metabolism of high D-glucose results in ROS liberation, and can generate damage in DNA, for instance, inducing DNA breaks (Garcia Soriano 
F et al., 2001). These DNA breaks induce the activation of Poly (ADP-ribose) polymerase (PARP), enzyme that stimulate the transcription of TET genes to repair DNA (Ciccarone et al., 2014). Tet enzymes hydroxylate 5-methylcytosine $(5 \mathrm{mC})$ to 5 -hydroxymethylcytosine $(5 \mathrm{hmC})$, which can also be oxidized to 5formylcytosine (5-fC) and 5-carboxycytosine ( $5 \mathrm{caC})$. Then the AID / APOBEC enzymes deaminate $5 \mathrm{mC}$ or $5 \mathrm{hmC}$ to 5 -methyluracil $(5 \mathrm{mU})$, and finally, by base cleavage, these intermediates ( $5 \mathrm{mU}, 5 \mathrm{hmU}$ or $5 \mathrm{caC}$ ) are replaced by a new cytosine, and therefore, demethylating the DNA (Bhutani et al., 2011; He et al., 2011; Wu et al., 2018). Reparation of DNA damage generates DNA hypomethylation through the hydroxylation of methylcytosine, giving rise to 5-hydroxymethylcytosine, an event that constitutes more than $90 \%$ of the reduction in cytosine methylation (Wu and Ni, 2015; Unnikrishnan et al., 2019).

Our results showed that hypomethylation in hEPC DNA was caused by of D-glucose metabolism and not by an osmotic effect (figure 6A). Moreover, an increased trend for $5 \mathrm{hmC}$ was observed at $10 \mathrm{mM}$ of $\mathrm{D}$ Glucose and this increase was statistically significative at $20 \mathrm{mM}(p<0.05)$ (figure $6 B$ ). This suggest that high $\mathrm{D}$-glucose concentration could be producing oxidative stress that stimulate DNA oxidation which is evidenced by the presence of $5 \mathrm{hmC}$.

Consistent with our results, Yuan's research group have reported an increase in $5 \mathrm{hmC}$ and global $5 \mathrm{mC}$ decreased in white blood cells (WBCs) isolated from patients type 2 diabetes patients (Yuan et al., 2019). Therefore, high D-glucose concentration may generate a dynamic change in the ratio of $5 \mathrm{mC}$ and $5 \mathrm{hmC}$ in circulating cells like WBCs and probably hEPC. At present, $5 \mathrm{hmC}$ is considered as the sixth base of DNA introducing an additional epigenetic code onto the genome (Ciccarone et al., 2015). In diabetes context, can be considered a new treatment biomarker, because changes in DNA methylation status appears before any alteration in cell function can be determined. Other study done in peripheral blood of type 2 diabetes patients, showed an elevated $5 \mathrm{hmC}$ levels in poorly glucose control patients with glycated hemoglobin $(H b A 1 c) \geq 7 \%(n=25)$ compared to good glycemic control patients with HbA1c< $7 \%(n=19)$ and healthy individuals $(n=35)$. This evidence reaffirms again the importance of maintaining a glycemia as close as possible to normal values.

In our study, the increase in $5 \mathrm{hmC}$ levels did not changes in expression level of RNA messenger for TET 1 or TET 2 genes (Figure 6C). These results are in contrast with Yuan's research group who observed an increase in the mRNA expression of TETs genes in WBCs obtained from type 2 diabetes patients. However, it has also been reported that expression of TETs enzymes can be regulated at the posttranslational level. In fact, it has been observed that IDAX protein (or CXXC4) can interact with the catalytic domain of TET2 to downregulate the TET2 protein through caspase mediated degradation (Ko et al., 2013). It has also been demonstrated that TETs protein are subject to a variety of post-translational modifications like phosphorylation and O-GlcNAcylation at the $\mathrm{N}$ terminus (Bauer et al., 2015). Thus, TET activity not only be regulated at the level of the RNA messenger, but it can also be regulated through post-translational modifications. Therefore, it is possible that a post-translational mechanism is regulating TET activity under different glycemic conditions. 
In summary, our results highlight the importance of maintain the glycemic levels as close to normal as possible, because high D-glucose concentration induces hypomethylation in hEPC genome before any cell function alteration can be detected.

Accordingly, in type 2 diabetes context, poor glycemic controls lead to sustained hyperglycemia over time, which can silently induce hypomethylation of hEPC genome, affecting the adhesion function of these cells and therefore impair microvascular repair in patients with type 2 diabetes.

\section{Declarations}

Ethics approval and consent to participate: This research was approved by the following committees:

- Bioethics and biosafety committee report Facultad de Ciencias Biológicas, University of Concepción.

- The Ethics, Bioethics and Biosafety Committee of the Vice President for Research and Development of the University of Concepción.

- Scientific ethics committee approval Concepción Health Service. Approval code: 19-10-102.

Consent for publication: Not applicable.

Availability of data and materials: The data sets generated and/or analyzed during this study are available at the following link https://www.icloud.com/iclouddrive/Of6elHljFQ0PGY3WbAwZ2Zprw\#Data_Fern\%C3\%A1ndezGarc\%C3\%A9s in the folder called "Data"

Competing interests: The authors declare that they have no competing interests.

Funding: This research was financed with funds from the National Commission for Scientific and Technological Research (Conicyt), currently the National Research and Development Agency (ANID).

Authors' contributions: All authors read and approved the final manuscrip

Acknowledgements: Not applicable.

\section{Authors' information:}

- PF is an academic of the Department of Medical Technology in the Universidad San Sebastian, in the city of Concepción, and is finishing her studies in the doctoral program in Biological Sciences at the Universidad de Concepción.

$-\mathrm{MH}$ is an academic and director of the Department of Medical Technology in the Faculty of Medicine at the University of Conception. 
- SG is an academic in the Department of Cellular and Molecular Biology and Dean of the Faculty of Biological Science at the University of Conception.

\section{References}

1. Alberti, K.G., and Zimmet, P.Z. (1998). Definition, diagnosis and classification of diabetes mellitus and its complications. Part 1: diagnosis and classification of diabetes mellitus provisional report of a WHO consultation. Diabet Med 15, 539-553.

2. Asahara, T., Murohara, T., Sullivan, A., Silver, M., van der Zee, R., Li, T., Witzenbichler, B., Schatteman, G., and Isner, J.M. (1997). Isolation of putative progenitor endothelial cells for angiogenesis. Science 275, 964-967.

3. Association, A.D. (2018). 6. Glycemic Targets:. Diabetes Care 41, S55-S64.

4. Balestrieri, M.L., Servillo, L., Esposito, A., D'Onofrio, N., Giovane, A., Casale, R., Barbieri, M., Paolisso, P., Rizzo, M.R., Paolisso, G., and Marfella, R. (2013). Poor glycaemic control in type 2 diabetes patients reduces endothelial progenitor cell number by influencing SIRT1 signalling via platelet-activating factor receptor activation. Diabetologia 56, 162-172.

5. Bauer, C., Göbel, K., Nagaraj, N., Colantuoni, C., Wang, M., Müller, U., Kremmer, E., Rottach, A., and Leonhardt, H. (2015). Phosphorylation of TET proteins is regulated via O-GIcNAcylation by the Olinked N-acetylglucosamine transferase (OGT). J Biol Chem 290, 4801-4812.

6. Bhutani, N., Burns, D.M., and Blau, H.M. (2011). DNA demethylation dynamics. Cell 146, 866-872.

7. Brownlee, M. (2001). Biochemistry and molecular cell biology of diabetic complications. Nature 414 , 813-820.

8. Cencioni, C., Spallotta, F., Greco, S., Martelli, F., Zeiher, A.M., and Gaetano, C. (2014). Epigenetic mechanisms of hyperglycemic memory. Int J Biochem Cell Biol 51, 155-158.

9. Chen, Y.H., Lin, S.J., Lin, F.Y., Wu, T.C., Tsao, C.R., Huang, P.H., Liu, P.L., Chen, Y.L., and Chen, J.W. (2007). High glucose impairs early and late endothelial progenitor cells by modifying nitric oxiderelated but not oxidative stress-mediated mechanisms. Diabetes 56, 1559-1568.

10. Chopra, H., Hung, M.K., Kwong, D.L., Zhang, C.F., and Pow, E.H.N. (2018). Insights into Endothelial Progenitor Cells: Origin, Classification, Potentials, and Prospects. Stem Cells Int 2018, 9847015.

11. Churdchomjan, W., Kheolamai, P., Manochantr, S., Tapanadechopone, P., Tantrawatpan, C., U-Pratya, Y., and Issaragrisil, S. (2010). Comparison of endothelial progenitor cell function in type 2 diabetes with good and poor glycemic control. BMC Endocr Disord 10, 5.

12. Ciccarone, F., Valentini, E., Bacalini, M.G., Zampieri, M., Calabrese, R., Guastafierro, T., Mariano, G., Reale, A., Franceschi, C., and Caiafa, P. (2014). Poly(ADP-ribosyl)ation is involved in the epigenetic control of TET1 gene transcription. Oncotarget 5, 10356-10367.

13. Ciccarone, F., Valentini, E., Zampieri, M., and Caiafa, P. (2015). 5mC-hydroxylase activity is influenced by the PARylation of TET1 enzyme. Oncotarget 6, 24333-24347. 
14. Dayeh, T., Volkov, P., Salö, S., Hall, E., Nilsson, E., Olsson, A.H., Kirkpatrick, C.L., Wollheim, C.B., Eliasson, L., Rönn, T., Bacos, K., and Ling, C. (2014). Genome-wide DNA methylation analysis of human pancreatic islets from type 2 diabetic and non-diabetic donors identifies candidate genes that influence insulin secretion. PLoS Genet 10, e1004160.

15. Dhliwayo, N., Sarras, M.P., Luczkowski, E., Mason, S.M., and Intine, R.V. (2014). Parp inhibition prevents ten-eleven translocase enzyme activation and hyperglycemia-induced DNA demethylation. Diabetes 63, 3069-3076.

16. Doumas, M., Imprialos, K., Stavropoulos, K., and Athyros, V.G. (2020). Pharmacological Management of Type 2 Diabetes Complications. Curr Vasc Pharmacol 18, 101-103.

17. Egan, C.G., Fondelli, C., Pierantozzi, E., Tripepi, G., Dotta, F., and Sorrentino, V. (2018). Putative endothelial progenitor cells predict long-term mortality in type-2 diabetes. Endocrine 62, 263-266.

18. Egan, C.G., Lavery, R., Caporali, F., Fondelli, C., Laghi-Pasini, F., Dotta, F., and Sorrentino, V. (2008). Generalised reduction of putative endothelial progenitors and CXCR4-positive peripheral blood cells in type 2 diabetes. Diabetologia 51, 1296-1305.

19. Federation, I.D. (2019). DIABETES ATLAS. In: IDF DIABETES ATLAS, ed. D.V.D.D. Design, 1-180.

20. Filippi, A., Constantin, A., Alexandru, N., Voicu, G., Constantinescu, C.A., Rebleanu, D., Fenyo, M., Simionescu, D., Simionescu, A., Manduteanu, I., and Georgescu, A. (2020). Integrins a4 $\beta 1$ and aV $\beta 3$ are Reduced in Endothelial Progenitor Cells from Diabetic Dyslipidemic Mice and May Represent New Targets for Therapy in Aortic Valve Disease. Cell Transplant 29, 963689720946277.

21. Forslund, J.M., and Archdeacon, M.T. (2015). The Pathobiology of Diabetes Mellitus in Bone Metabolism, Fracture Healing, and Complications. Am J Orthop (Belle Mead NJ) 44, 453-457.

22. Fu, D., Zhao, H., He, L., and Feng, H. (2020). DM-induced Hypermethylation of IR and IGF1R attenuates mast cell activation and airway responsiveness in rats. J Cell Mol Med 24, 14381-14391.

23. Garcia Soriano F, Virág, L., Jagtap, P., Szabó, E., Mabley, J.G., Liaudet, L., Marton, A., Hoyt, D.G., Murthy, K.G., Salzman, A.L., Southan, G.J., and Szabó, C. (2001). Diabetic endothelial dysfunction: the role of poly(ADP-ribose) polymerase activation. Nat Med 7, 108-113.

24. Gong, Y.Y., Liu, Y.Y., Li, J., Su, L., Yu, S., Zhu, X.N., Cao, X.P., and Xiao, H.P. (2014). Hypermethylation of Cox5a promoter is associated with mitochondrial dysfunction in skeletal muscle of high fat dietinduced insulin resistant rats. PLoS One 9, e113784.

25. Guo, Y., Huang, Z., Sang, D., Gao, Q., and Li, Q. (2020). The Role of Nutrition in the Prevention and Intervention of Type 2 Diabetes. Front Bioeng Biotechnol 8, 575442.

26. Hamed, S., Brenner, B., Aharon, A., Daoud, D., and Roguin, A. (2009). Nitric oxide and superoxide dismutase modulate endothelial progenitor cell function in type 2 diabetes mellitus. Cardiovasc Diabetol 8, 56.

27. He, Y.F., Li, B.Z., Li, Z., Liu, P., Wang, Y., Tang, Q., Ding, J., Jia, Y., Chen, Z., Li, L., Sun, Y., Li, X., Dai, Q., Song, C.X., Zhang, K., He, C., and Xu, G.L. (2011). Tet-mediated formation of 5-carboxylcytosine and its excision by TDG in mammalian DNA. Science 333, 1303-1307. 
28. Henning, R.J. (2018). Type-2 diabetes mellitus and cardiovascular disease. Future Cardiol 14, 491509.

29. Holman, R.R., Paul, S.K., Bethel, M.A., Matthews, D.R., and Neil, H.A. (2008). 10-year follow-up of intensive glucose control in type 2 diabetes. N Engl J Med 359, 1577-1589.

30. Jujo, K., li, M., and Losordo, D.W. (2008). Endothelial progenitor cells in neovascularization of infarcted myocardium. J Mol Cell Cardiol 45, 530-544.

31. Kang, H., Ma, X., Liu, J., Fan, Y., and Deng, X. (2017). High glucose-induced endothelial progenitor cell dysfunction. Diab Vasc Dis Res 14, 381-394.

32. Ko, M., An, J., Bandukwala, H.S., Chavez, L., Aijö, T., Pastor, W.A., Segal, M.F., Li, H., Koh, K.P., Lähdesmäki, H., Hogan, P.G., Aravind, L., and Rao, A. (2013). Modulation of TET2 expression and 5methylcytosine oxidation by the CXXC domain protein IDAX. Nature 497, 122-126.

33. Ling, C., and Rönn, T. (2019). Epigenetics in Human Obesity and Type 2 Diabetes. Cell Metab 29, 1028-1044.

34. Lio, C.J., and Rao, A. (2019). TET Enzymes and 5hmC in Adaptive and Innate Immune Systems. Front Immunol 10, 210.

35. Marçola, M., and Rodrigues, C.E. (2015). Endothelial progenitor cells in tumor angiogenesis: another brick in the wall. Stem Cells Int 2015, 832649.

36. Nilsson, E., Matte, A., Perfilyev, A., de Mello, V.D., Käkelä, P., Pihlajamäki, J., and Ling, C. (2015). Epigenetic Alterations in Human Liver From Subjects With Type 2 Diabetes in Parallel With Reduced Folate Levels. J Clin Endocrinol Metab 100, E1491-1501.

37. Ouni, M., Saussenthaler, S., Eichelmann, F., Jähnert, M., Stadion, M., Wittenbecher, C., Rönn, T., Zellner, L., Gottmann, P., Ling, C., Schulze, M.B., and Schürmann, A. (2020). Epigenetic Changes in Islets of Langerhans Preceding the Onset of Diabetes. Diabetes 69, 2503-2517.

38. Parveen, N., and Dhawan, S. (2021). DNA Methylation Patterning and the Regulation of Beta Cell Homeostasis. Front Endocrinol (Lausanne) 12, 651258.

39. Patel, A., MacMahon, S., Chalmers, J., Neal, B., Billot, L., Woodward, M., Marre, M., Cooper, M., Glasziou, P., Grobbee, D., Hamet, P., Harrap, S., Heller, S., Liu, L., Mancia, G., Mogensen, C.E., Pan, C., Poulter, N., Rodgers, A., Williams, B., Bompoint, S., de Galan, B.E., Joshi, R., Travert, F., and Group, A.C. (2008). Intensive blood glucose control and vascular outcomes in patients with type 2 diabetes. $N$ Engl J Med 358, 2560-2572.

40. Pearson, J.D. (2009). Endothelial progenitor cells - hype or hope? J Thromb Haemost 7, 255-262.

41. Pinzón-Cortés, J.A., Perna-Chaux, A., Rojas-Villamizar, N.S., Díaz-Basabe, A., Polanía-Villanueva, D.C., Jácome, M.F., Mendivil, C.O., Groot, H., and López-Segura, V. (2017). Effect of diabetes status and hyperglycemia on global DNA methylation and hydroxymethylation. Endocr Connect 6, 708-725.

42. Saeedi, P., Petersohn, I., Salpea, P., Malanda, B., Karuranga, S., Unwin, N., Colagiuri, S., Guariguata, L., Motala, A.A., Ogurtsova, K., Shaw, J.E., Bright, D., Williams, R., and Committee, I.D.A. (2019). Global and regional diabetes prevalence estimates for 2019 and projections for 2030 and 2045: Results from the International Diabetes Federation Diabetes Atlas, 9. Diabetes Res Clin Pract 157, 107843. 
43. Sambuceti, G., Morbelli, S., Vanella, L., Kusmic, C., Marini, C., Massollo, M., Augeri, C., Corselli, M., Ghersi, C., Chiavarina, B., Rodella, L.F., L'Abbate, A., Drummond, G., Abraham, N.G., and Frassoni, F. (2009). Diabetes impairs the vascular recruitment of normal stem cells by oxidant damage, reversed by increases in pAMPK, heme oxygenase-1, and adiponectin. Stem Cells 27, 399-407.

44. Schmidt, A.M. (2018). Highlighting Diabetes Mellitus: The Epidemic Continues. Arterioscler Thromb Vasc Biol 38, e1-e8.

45. Sorrentino, S.A., Bahlmann, F.H., Besler, C., Müller, M., Schulz, S., Kirchhoff, N., Doerries, C., Horváth, T., Limbourg, A., Limbourg, F., Fliser, D., Haller, H., Drexler, H., and Landmesser, U. (2007). Oxidant stress impairs in vivo reendothelialization capacity of endothelial progenitor cells from patients with type 2 diabetes mellitus: restoration by the peroxisome proliferator-activated receptor-gamma agonist rosiglitazone. Circulation 116,163-173.

46. Tepper, O.M., Galiano, R.D., Capla, J.M., Kalka, C., Gagne, P.J., Jacobowitz, G.R., Levine, J.P., and Gurtner, G.C. (2002). Human endothelial progenitor cells from type II diabetics exhibit impaired proliferation, adhesion, and incorporation into vascular structures. Circulation 106, 2781-2786.

47. Tewari, S., Zhong, Q., Santos, J.M., and Kowluru, R.A. (2012). Mitochondria DNA replication and DNA methylation in the metabolic memory associated with continued progression of diabetic retinopathy. Invest Ophthalmol Vis Sci 53, 4881-4888.

48. UK Prospective Diabetes Study (UKPDS) Group. (1998). Effect of intensive blood-glucose control with metformin on complications in overweight patients with type 2 diabetes (UKPDS 34). Lancet 352, 854-865.

49. Unnikrishnan, A., Freeman, W.M., Jackson, J., Wren, J.D., Porter, H., and Richardson, A. (2019). The role of DNA methylation in epigenetics of aging. Pharmacol Ther 195, 172-185.

50. Vasa, M., Fichtlscherer, S., Aicher, A., Adler, K., Urbich, C., Martin, H., Zeiher, A.M., and Dimmeler, S. (2001). Number and migratory activity of circulating endothelial progenitor cells inversely correlate with risk factors for coronary artery disease. Circ Res 89, E1-7.

51. Weitzman, S.A., Turk, P.W., Milkowski, D.H., and Kozlowski, K. (1994). Free radical adducts induce alterations in DNA cytosine methylation. Proc Natl Acad Sci U S A 91, 1261-1264.

52. Wu, Q., and Ni, X. (2015). ROS-mediated DNA methylation pattern alterations in carcinogenesis. Curr Drug Targets 16,13-19.

53. Wu, X., Li, G., and Xie, R. (2018). Decoding the role of TET family dioxygenases in lineage specification. Epigenetics Chromatin 11, 58.

54. Wu, Y., Cui, W., Zhang, D., Wu, W., and Yang, Z. (2017). The shortening of leukocyte telomere length relates to DNA hypermethylation of LINE-1 in type 2 diabetes mellitus. Oncotarget 8, 73964-73973.

55. Xing, Z., Zhao, C., Liu, H., and Fan, Y. (2020). Endothelial Progenitor Cell-Derived Extracellular Vesicles: A Novel Candidate for Regenerative Medicine and Disease Treatment. Adv Healthc Mater, e2000255.

56. Yuan, E.F., Yang, Y., Cheng, L., Deng, X., Chen, S.M., Zhou, X., and Liu, S.M. (2019). Hyperglycemia affects global 5-methylcytosine and 5-hydroxymethylcytosine in blood genomic DNA through 
upregulation of SIRT6 and TETs. Clin Epigenetics 11, 63.

57. Yue, W.S., Lau, K.K., Siu, C.W., Wang, M., Yan, G.H., Yiu, K.H., and Tse, H.F. (2011). Impact of glycemic control on circulating endothelial progenitor cells and arterial stiffness in patients with type 2 diabetes mellitus. Cardiovasc Diabetol 10,113.

58. Zhang, L., Lu, Q., and Chang, C. (2020). Epigenetics in Health and Disease. Adv Exp Med Biol 1253, $3-55$.

\section{Table}

TABLE 1: Clinical characteristic of blood donors:

\begin{tabular}{lllll} 
ID & Age (years) & Weight $(\mathrm{kg})$ & Height $(\mathrm{cm})$ & Glycemia $(\mathrm{mg} / \mathrm{dl})$ \\
\hline M1 & 31 & 77 & 175 & 86,2 \\
\hline M2 & 31 & 57 & 156 & 88,3 \\
\hline M3 & 28 & 78 & 177 & 88,2 \\
\hline M4 & 30 & 81 & 179 & 76,1
\end{tabular}

\section{Figures}


FIGURE 1:

A.

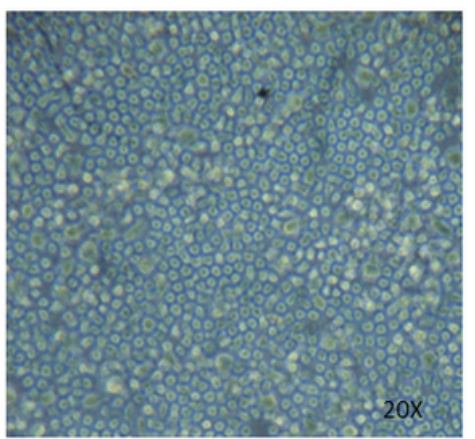

B.

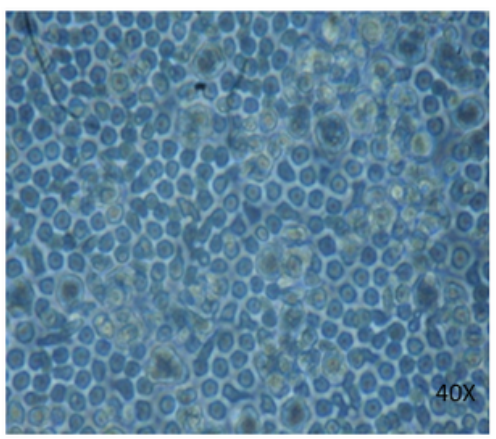

C.

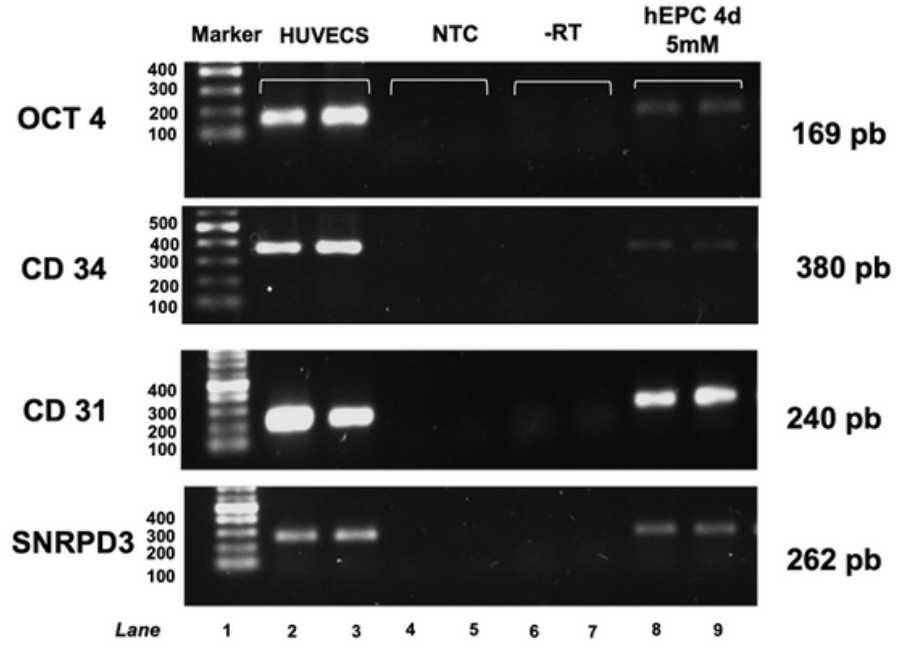

D.
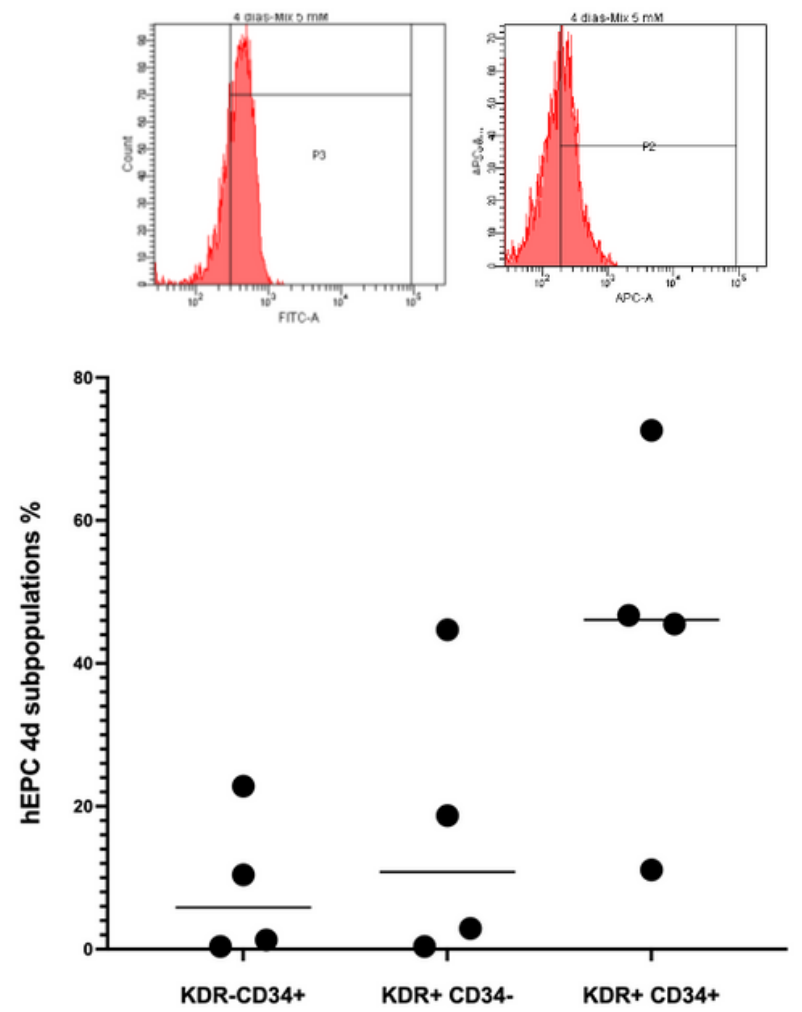

NTC: no template control

\section{Figure 1}

\section{hEPC characterization.}

(A) hEPC cultured a $5 \mathrm{mM}$ of D-Glucose are show at 20x and (B) $40 x$ magnification. The images are representative of 5 fields. (C) The presence of mRNA for immaturity marker Oct-4 /CD34 and endothelial marker CD31, in hEPC cultured for four days with $5 \mathrm{mM}$ D-Glucose was evaluated by conventional PCR and visualized by electrophoresis. CDNA of HUVECs cells was used as positive control and SRNPD3 gene 
was used as load control (n=3). (D) The presence of protein KDR, CD34 and CD31 was evaluated by flow cytometry $(n=4)$. The results were analyzed by ANOVA test, * $p>0.01$.

\section{FIGURE 2:}

A.

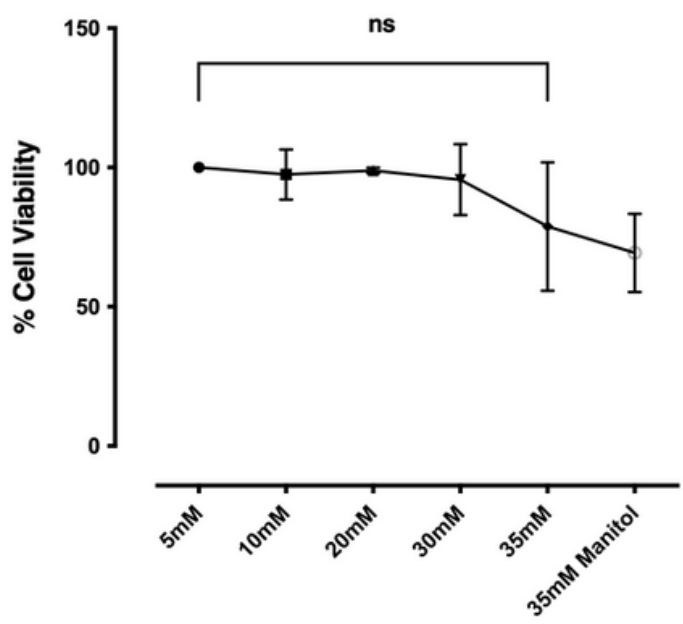

D-Glucose concentrations

C.

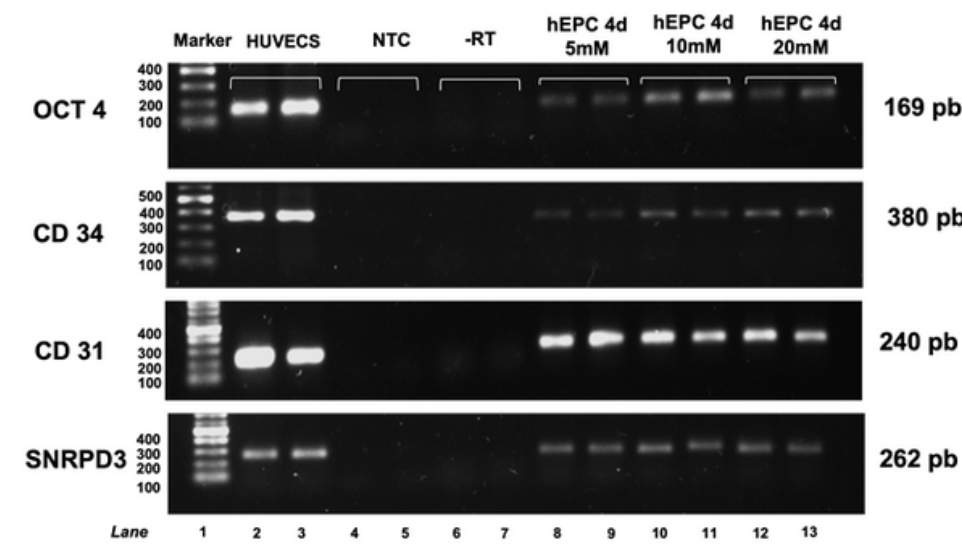

NTC: no template control
B.

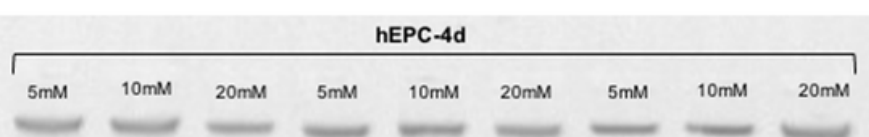

D.
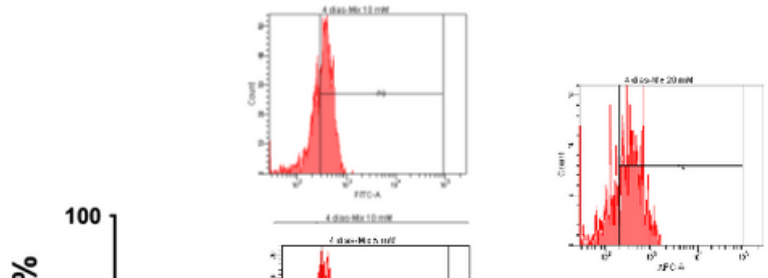

음

을

60
40
20
0
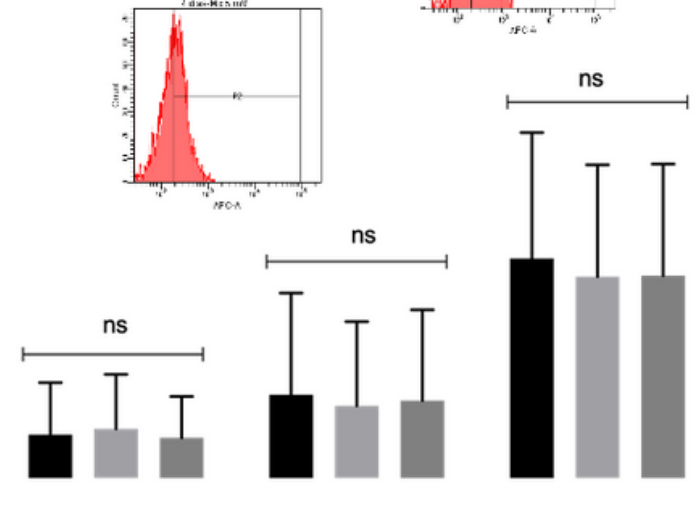

KDR-CD34+

KDR+ CD34-

KDR+ CD34+

- $5 \mathrm{mM} \mathrm{D-Glucosa}$

10mM D-Glucosa

20mM D-Glucosa

ns: no statistical significance

Figure 2

Characterization of hEPC cultured in high D- glucose concentration 
(A) Cell viability of hEPC cultured in different concentrations of D-glucose $(5,10,20,30$ and $35 \mathrm{mM})$ was evaluated; mannitol was used as osmotic control $(n=4)$. (B) Fragmentation of genomic DNA of hEPC cultured at $10 \mathrm{mM}$ and $20 \mathrm{mM}$ D-glucose was analyzed by electrophoresis. (C) The presence of mRNA for immaturity marker Oct-4 /CD34 and endothelial marker CD31, in hEPC cultured for four days with 5mM, $10 \mathrm{mM}$ and $20 \mathrm{mM}$ of D-Glucose was evaluated by conventional PCR and visualized by electrophoresis. CDNA of HUVECs cells was used as positive control and SRNPD3 gene was used as load control $(\mathrm{n}=4)$. (D) The presence of KDR, CD34 and CD31 in hEPC cultured at $5 \mathrm{mM}, 10 \mathrm{mM}$ and $20 \mathrm{mM}$ of D- glucose was evaluated by flow cytometry $(n=4)$. The results were analyzed by ANOVA test, $* \star p>0.01$. 
FIGURE 3:

A.

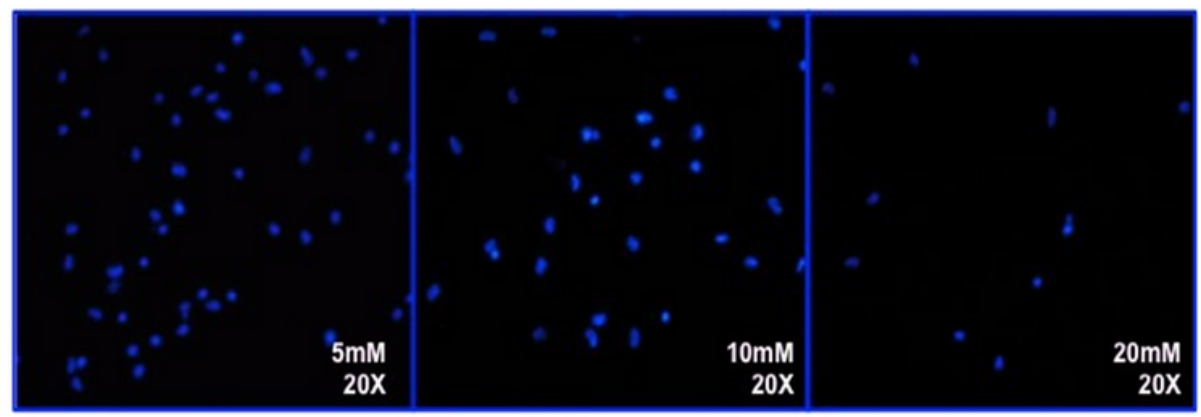

*

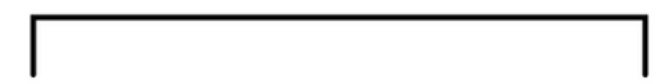

B.

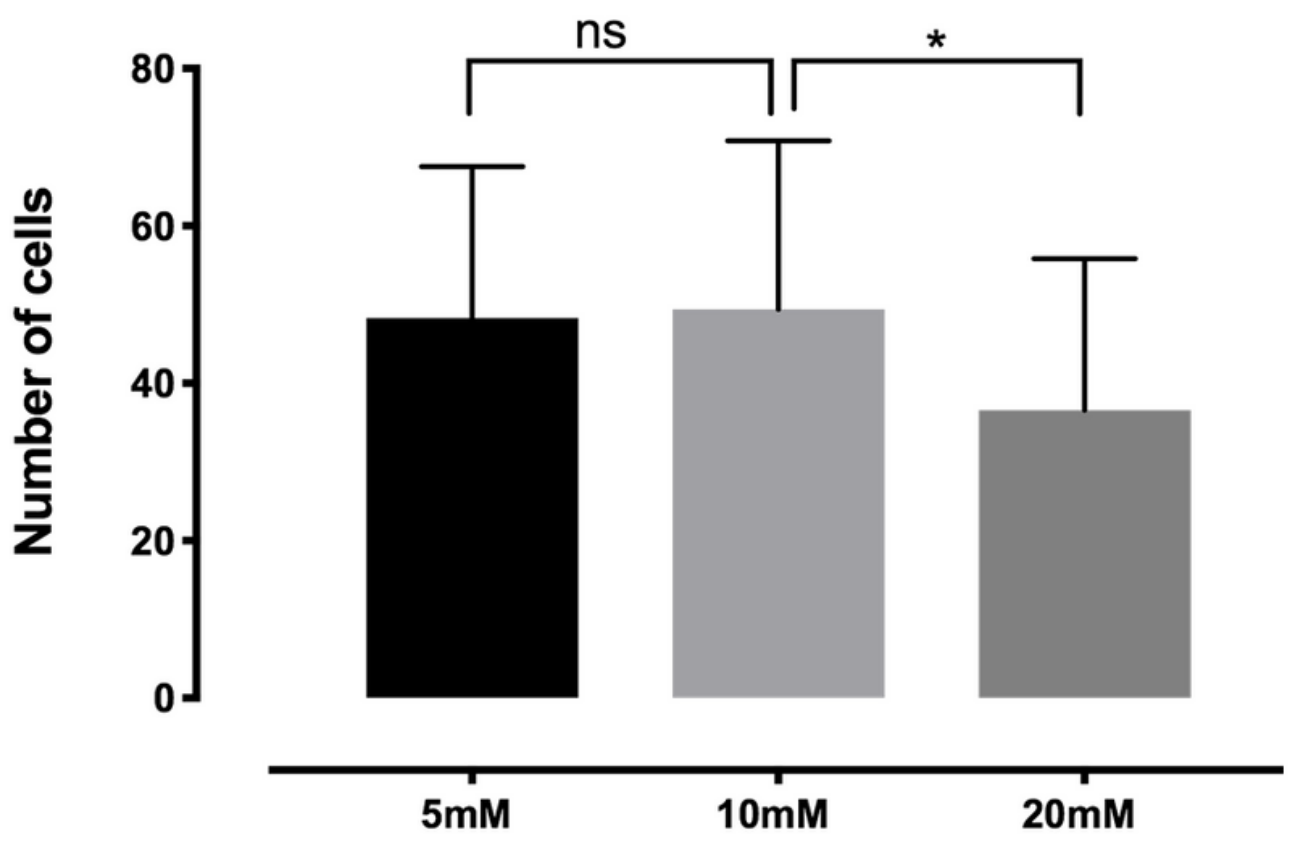

ns: no statistical significance

D-Glucose concentrations

Figure 3

Adhesion of hEPC decrease in presence of high D-glucose concentrations.

(A) Fibronectin matrix adhesion of hEPC cultured for four days at $5 \mathrm{mM}, 10 \mathrm{mM}$ and $20 \mathrm{mM}$ of D-glucose are show at 20x magnification by fluorescence microscopy. The images are representative of 5 fields per culture condition $(n=4)$. (B) Cell count number of hEPC cultured at $5 \mathrm{mM}, 10 \mathrm{mM}$ and $20 \mathrm{mM}$ of Dglucose adhered to the fibronectin matrix. The results were analyzed by ANOVA test $\left({ }^{*} p>0.05\right)$. 
FIGURE 4:

A.

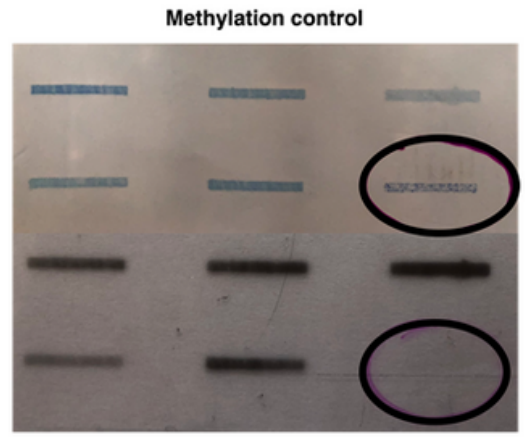

B.

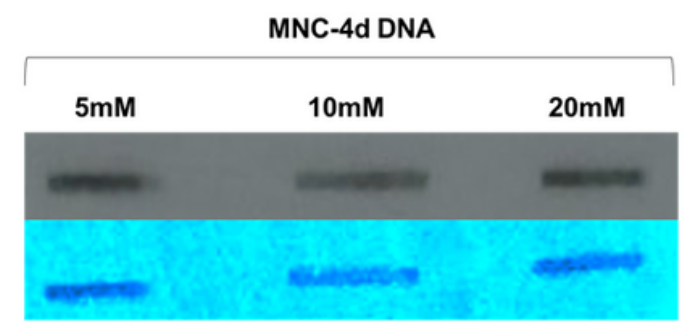

*

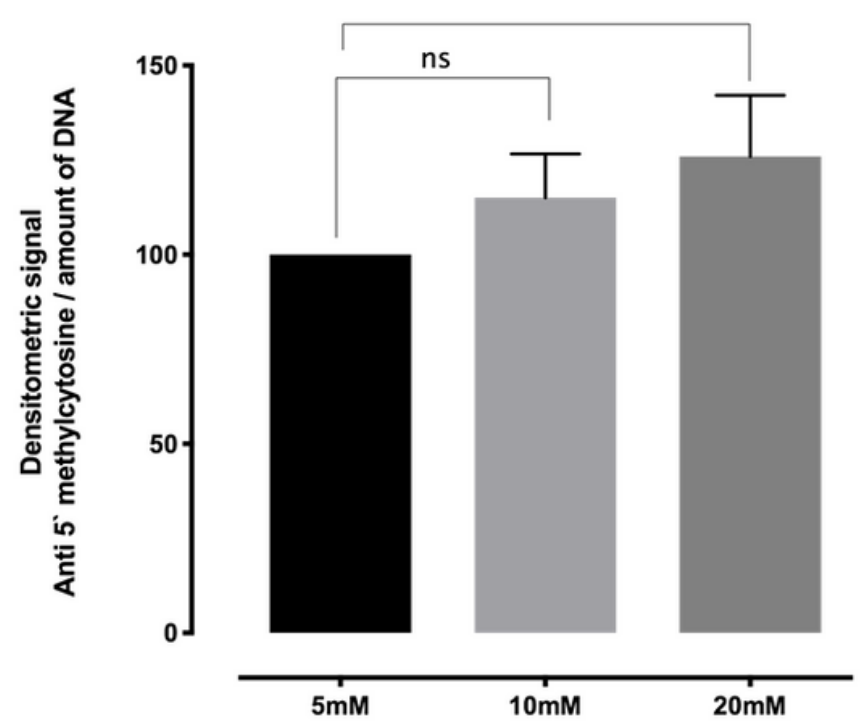

D-Glucose concentrations
C.

\begin{tabular}{|c|c|c|c|}
\hline \multicolumn{3}{|c|}{ hEPC-4d DNA } & \\
\hline $5 \mathrm{mM}$ & $10 \mathrm{mM}$ & $20 \mathrm{mM}$ & \\
\hline ensmeses & Denseses & 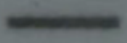 & Film \\
\hline eevanom & atemes & wencestes & Membrane \\
\hline
\end{tabular}

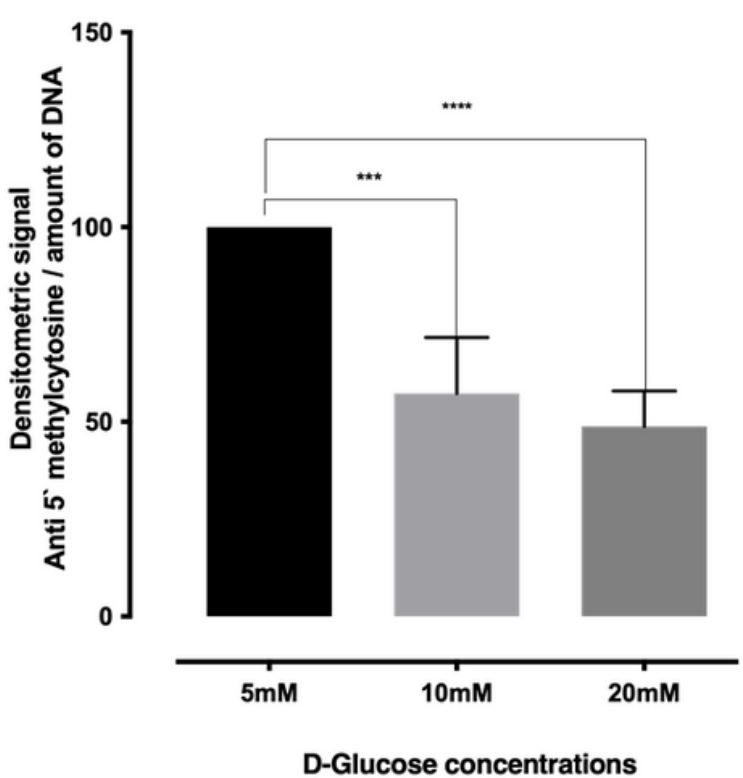

ns: no statistical significance

Figure 4

hEPC cultured in high D-glucose concentration show a decrease in the percentage of DNA methylation.

(A) Slot Blot of DNA from a PCR product and genomic DNA were used as a control for specificity Primary anti-5'methylcytosine antibody. (B) Slot blot for genomic DNA of mononuclear cells (MNCs) and (C) genomic DNA of hEPC cultured in $5 \mathrm{mM}, 20 \mathrm{mM}$ and $20 \mathrm{mM}$ of D-glucose was performed using a specificity primary anti-5'methylcytosine antibody. All densitometric analysis of the bands was carried out 


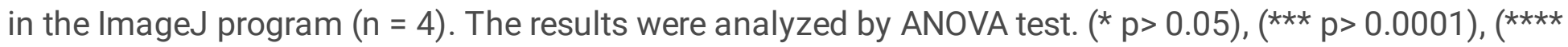
$p>0.0001)$.

FIGURE 5:

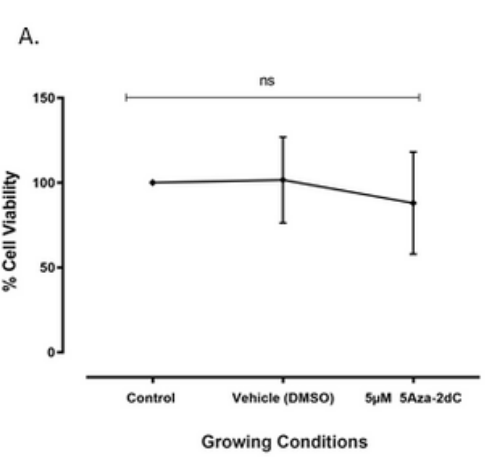

B.

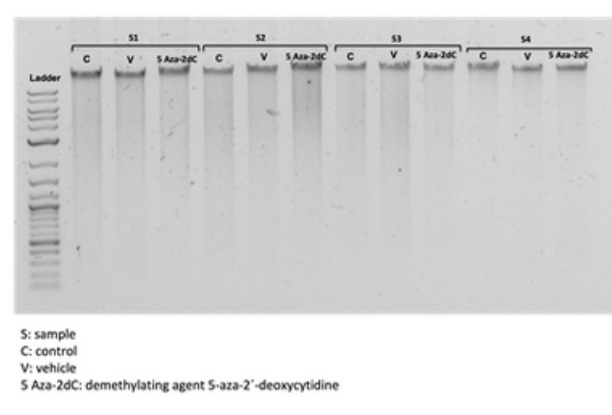

D.
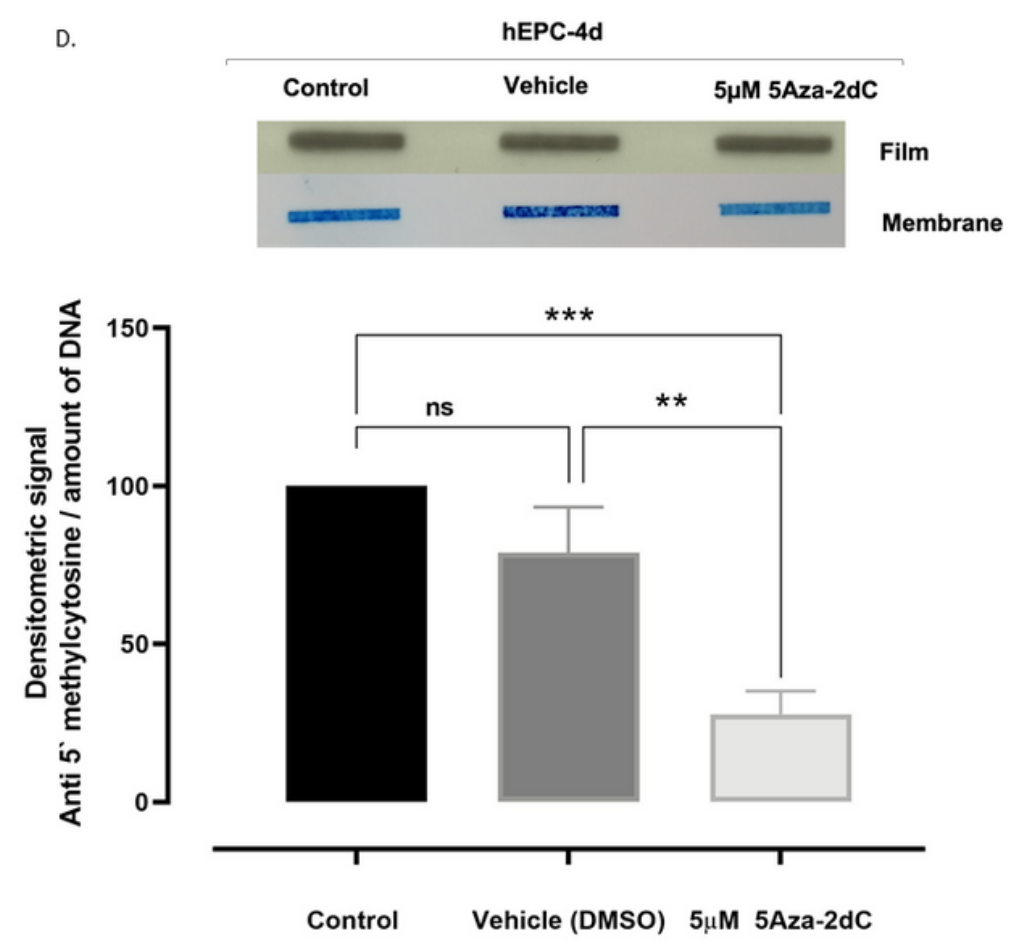

Growing Conditions

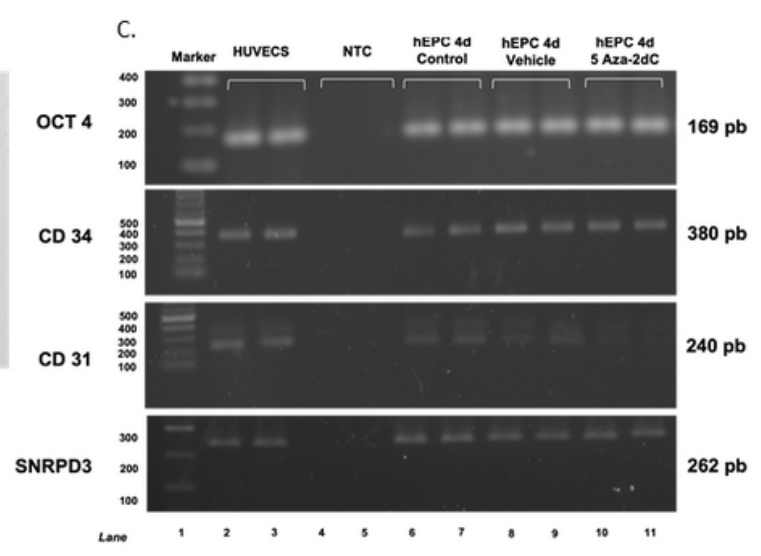

E.
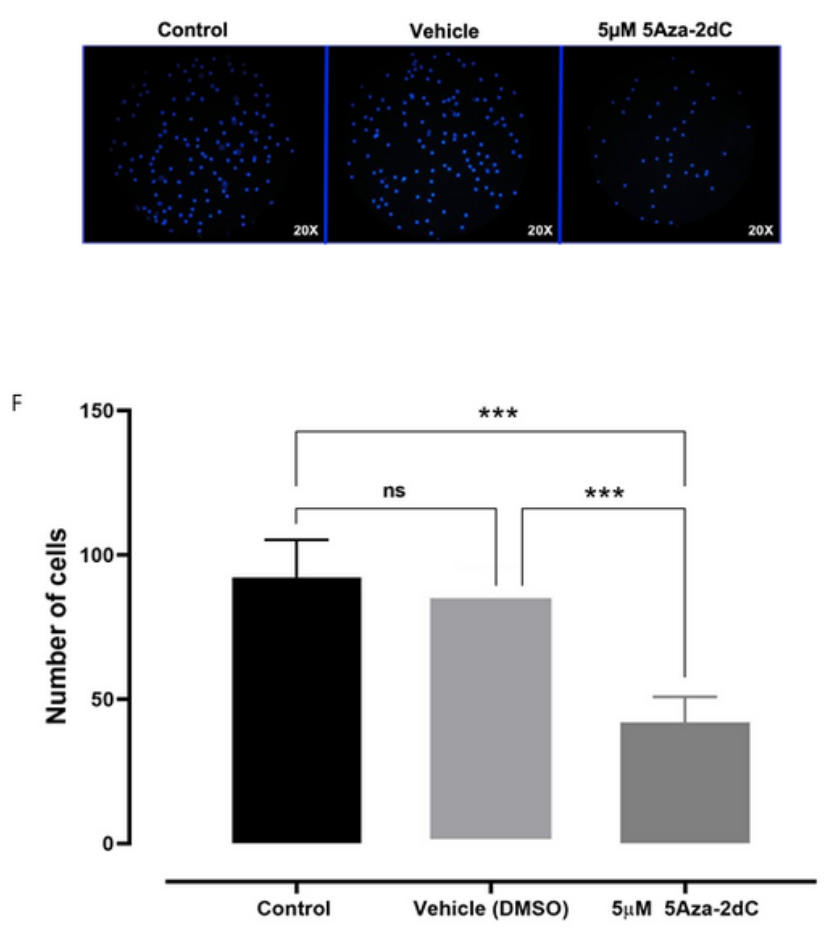

Growing Conditions

ns: no statistical significance NTC: no template control

\section{Figure 5}

Decreased adhesion of hEPC is related to global hypomethylation of the genome. 
(A) Cell viability of hEPC cultured for 24 hours in control conditions (5mM of D-Glucose), with vehicle (DMSO) and 5 $\mu \mathrm{M}$ 5-Aza-dC. (B) Fragmentation of genomic DNA of hEPC cultured for 24 hours with $5 \mathrm{mM}$ of D-Glucose, in vehicle (DMSO) and 5 $\mu \mathrm{M} 5$-Aza-dC was analyzed by electrophoresis. (C) mRNA for immaturity marker Oct-4 /CD34 and endothelial marker CD31, in hEPC cultured for 24 hours with $5 \mathrm{mM}$ of D-Glucose, in vehicle (DMSO) and 5 $\mu \mathrm{M} 5$-Aza-dC was evaluated by conventional PCR and visualized by electrophoresis. CDNA of HUVECs cells was used as positive control and SRNPD3 gene was used as load control $(n=4)$.

(D) Slot Blot for genomic DNA of hEPC grown for 24 hours with $5 \mathrm{mM}$ of D-Glucose, in vehicle (DMSO) and $5 \mu \mathrm{M}$ 5-Aza-dC was performed using specificity primary anti-5'methylcytosine antibody. All densitometric analysis of the bands was carried out in the ImageJ program $(n=4)$.

(E) Fibronectin matrix adhesion hEPC cultured for 24 hours with $5 \mathrm{mM}$ of D-Glucose, in vehicle (DMSO) and $5 \mu \mathrm{M} 5-A z a-d C$ are show at 20x magnification by fluorescence microscopy. The images are representative of 5 fields per culture condition $(n=4)$. (F) Cell count number of hEPC cultured for 24 hours with $5 \mathrm{mM}$ of D-Glucose, in vehicle (DMSO) and $5 \mu \mathrm{M} 5$-Aza-dC $(n=4)$. The results were analyzed by ANOVA test. (** $p>0.01),(\star \star \star ~ p>0.001)$. 
FIGURE 6:
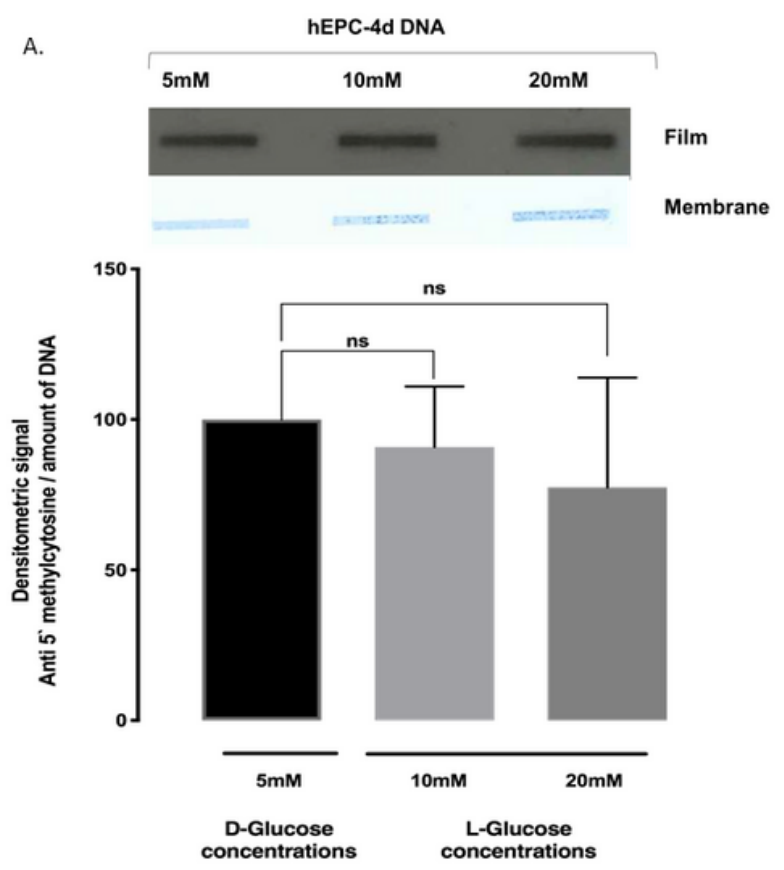

c.

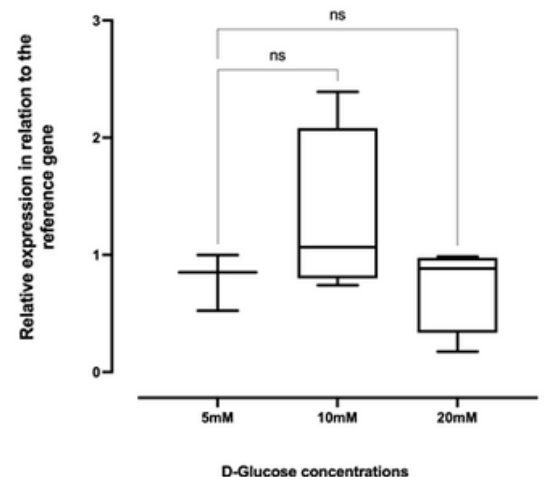

D-Glucose concentrations
B.
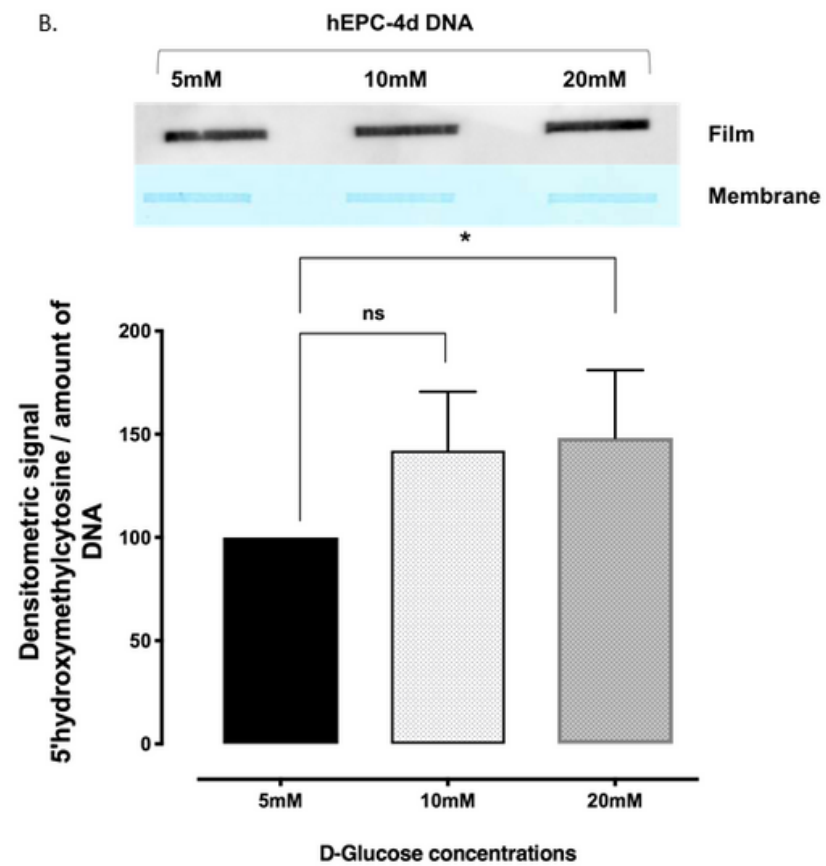

E.

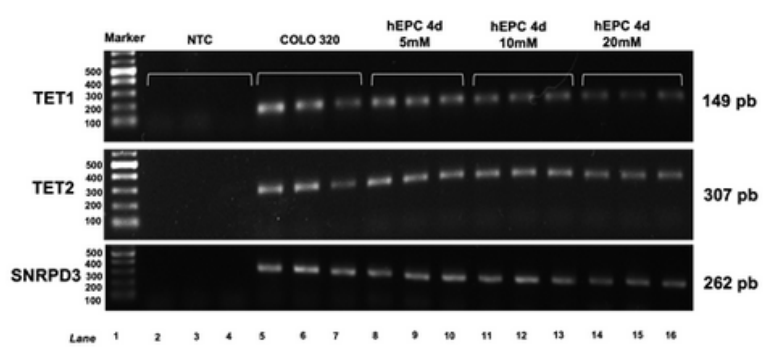

ns: no statistical significance

Figure 6

High D-Glucose increases $5 \mathrm{hmC}$, but not the expression of TET enzymes:

(A) Slot Blot for genomic DNA of hEPC grown in media supplemented with $5 \mathrm{mM}$ of D-glucose, $10 \mathrm{mM}$ or $20 \mathrm{mM}$ of L-glucose was performed using anti-5'methylcytosine primary antibody $(n=3)$. (B) Slot Blot for genomic DNA of hEPC grown with $5 \mathrm{mM}, 10 \mathrm{mM}$ and $20 \mathrm{mM}$ of D-glucose was performed using anti-5' hydroxymethylcytosine primary antibody $(n=4)$. All densitometric analysis of the bands was carried out in the Image J program. mRNA expression levels for the TET 1 (C) and TET2 (D) genes of hEPCs grown 
with $5 \mathrm{mM}, 10 \mathrm{mM}$ and $20 \mathrm{mM}$ D-Glucose was evaluated using $\mathrm{PPCR}$, and the results were analyzed using DDCt method and melting curve analysis. As expression positive control cDNA from COLO320 cells was used, and SRNPD3 gene was used as housekeeping $(\mathrm{n}=4)$. (E) The presence of mRNA for TET1 and TET2 genes, in hEPC cultured for four days with $5 \mathrm{mM}, 10 \mathrm{mM}$ and $20 \mathrm{mM}$ of D-Glucose was evaluated by qPCR and visualized by electrophoresis. CDNA of COLO320 cells was used as positive control and SRNPD3 gene was used as load control $(\mathrm{n}=3)$. The results were analyzed by ANOVA test (ns= not statistically significant). 